\title{
Astronomia no Meio do Mundo: uma análise Física da visualização de constelações e dos equinócios e solstícios a partir da Latitude Zero
}

\author{
José Nilson da Silva ${ }^{1}$ \\ Marcos Rincon Voelzke ${ }^{2}$ \\ Mauro Sérgio Teixeira de Araújo ${ }^{3}$ \\ Universidade Cruzeiro do Sul \\ São Paulo - SP
}

\section{Resumo}

Embora fenômenos astronômicos façam parte do cotidiano das pessoas, pouco se divulga sobre suas peculiaridades para um observador sobre a linha do equador, como na cidade de Macapá-AP, localizada à latitude zero. Assim, este trabalho visa dar suporte ao ensino de Física tendo como foco a correta difusão de alguns fenômenos astronômicos a partir de um observador à latitude zero, destacando a visualização da esfera celeste e evidenciando quais constelações são visíveis durante o ano, sendo proposta a elaboração de um planisfério para esta latitude. Também são tratados os Solstícios e, mais especificamente, os Equinócios, e suas particularidades para um observador à latitude zero. A abordagem oferecida pode auxiliar professores de Física e de Ciências que atuam na educação básica a explorarem nas escolas esses importantes fenômenos astronômicos.

Palavras-chave: Astronomia; Carta Celeste; Equinócio; Latitude Zero.

\begin{abstract}
Although Astronomy is part of everyday life of the people, peculiarities are little-known for an observer on the equator, as residents in Macapá-
\end{abstract}

\footnotetext{
${ }^{+}$Astronomy in the Middle of the World: a physical analysis of the astronomic phenomena at Latitude Zero

* Recebido: maio de 2017.

Aceito: dezembro de 2017.

${ }^{1}$ E-mail: nilsonjns@hotmail.com; ${ }^{2}$ E-mail: mrvoelzke@ hotmail.com;

${ }^{3}$ E-mail: mauro.araujo@cruzeirodosul.edu.br
} 
AP, located at Latitude Zero. So, this work aims to support physics teaching focusing on the correct diffusion of some physical phenomena which have an intrinsic relationship with Astronomy from the sight of an observer at latitude zero, highlighting the celestial sphere visualization and emphasizing which constellations are visible during an earth year, being proposed the elaboration of a planisphere to this latitude. It's also discussed about the Solstices and, more specifically, about the Equinoxes and their particularities for an observer in latitude zero. The offered approach can help teachers of Physics and Science who work in regular education schools to explore these important astronomical phenomena.

Keywords: Astronomy; Celestial Chart; Equinox; Latitude Zero.

\section{Introdução}

A Astronomia é uma ciência que estimula a curiosidade humana desde tempos remotos e atualmente existem diversas pesquisas voltadas a divulgar os conhecimentos desta área. Considerando a importância da observação astronômica, este trabalho consiste em apresentar uma análise física de alguns fenômenos astronômicos a partir da latitude zero, ou do meio do mundo como os macapaenses costumam denominar a posição geográfica da cidade de Macapá.

A cidade de Macapá-AP está localizada no extremo norte do Brasil e apresenta algumas características naturais peculiares, como ser a única capital brasileira banhada pelo rio Amazonas e também por estar situada sobre a linha imaginária que divide o planeta em dois hemisférios, ou seja, a linha do equador. A peculiaridade relativa à sua posição geográfica torna esta cidade uma base de observação física relevante para a abordagem dos temas tratados nesta proposta de atividade de ensino.

Cabe ressaltar que o ensino de tópicos de Astronomia é defendido por diferentes autores (BRETONES, 2015; LANGUI, 2017; IACHEL et al., 2009; ELIAS; AMARAL; ARAÚJO, 2007), sendo o mesmo apoiado pela União Astronômica Internacional (IAU). Neste sentido, Langui (2017, p. e4303) aponta que "A IAU possui a Comissão 46 (Ensino), cuja finalidade é desenvolver, aperfeiçoar e disseminar informações concernentes à Educação em Astronomia em todos os níveis do mundo mediante vários projetos". Favorecendo a disseminação desses conhecimentos astronômicos, Bretones, Megid Neto e Canalle (2006, p. 6) destacam que "o campo da Educação em Astronomia vem sendo considerado com relativa importância nas reuniões da SAB" (Sociedade Astronômica Brasileira), o que tende a contribuir para que seja ampliado o espaço de divulgação e aquisição de conhecimentos nesta área.

A fundamentação teórica deste trabalho engloba dois importantes conteúdos relacionados à Astronomia: o céu noturno observável de acordo com a localização geográfica do observador e os Equinócios. Os dois temas são relevantes ao conhecimento dos professores 
em formação ou em exercício, tendo em vista a defesa de sua abordagem ao longo da educação fundamental e média conforme apontam documentos oficiais.

Todo astrônomo, profissional ou amador, efetua suas observações astronômicas a olho nu ou com o auxílio de instrumentos ópticos, como o telescópio, a partir de um determinado local sobre o globo terrestre e, dependendo da latitude onde se encontre, assim como da época do ano, ele observará uma parcela diferente da esfera celeste. Desse modo, como ponto de partida, é feita uma abordagem sobre a questão da parcela da esfera celeste que pode ser observada, durante um ano terrestre, a partir da linha do equador, utilizando-se como parâmetro comparativo as Cartas Celestes de três cidades situadas em Latitudes diferentes, para o ano de 2016. Visando facilitar a propagação deste conhecimento para o sistema educacional de modo a auxiliar a atuação docente na área de Física, é proposta a montagem de um planisfério para um observador à Latitude zero.

Na sequência, é apresentado outro fenômeno de relevante destaque para Macapá, quando comparado a outras regiões, que é o Equinócio, festejado duas vezes por ano, primavera e outono, nos meses de março e setembro, sendo o primeiro conhecido localmente como o Equinócio das águas.

Para a análise do Equinócio é feita uma abordagem dos fatores que o determinam, ou seja, a inclinação do eixo terrestre e a posição relativa entre a Terra e o Sol. Porém, é dada ênfase sobre a perspectiva do mesmo a partir da Latitude zero, explicando quais as especificidades deste fenômeno para um observador posicionado sobre a linha do equador, como o fazem aqueles que o presenciam a partir do monumento marco-zero do equador, no Estado do Amapá.

Visando efetuar a análise destes fenômenos, são utilizadas figuras ilustrativas e alguns princípios básicos de Física para a compreensão das suas ocorrências. As explicações dos fenômenos dispensam maior complexidade, visto que o objetivo deste trabalho é colaborar com o ensino de Física na educação básica, corrigindo conclusões precipitadas e sem teor científico de algumas interpretações propagadas a respeito da ocorrência de alguns fenômenos à Latitude zero.

\section{O céu visto a partir da linha do equador: um observatório natural privilegiado}

A bela e tradicional constelação* Cruzeiro do sul é vista acompanhada de duas estrelas guardiãs, alfa e beta do centauro. Porém, tais astros não são visíveis para observadores situados no hemisfério norte, nas proximidades do Polo. Por sua vez, o asterismo big dipper (Grande Panela, em uma tradução livre em português), em Ursa maior, é uma joia do norte não visível no hemisfério sul, próximo do Polo oposto. É possível citar outros exemplos do

\footnotetext{
* Padronizou-se pela União Astronômica Internacional (IAU) que a abóbada celeste é dividida em 88 partes, denominadas constelações, onde suas estrelas possuem uma aproximação aparente - quando vistos do céu noturno terrestre - mas que podem estar muito distantes umas das outras (LANGHI; NARDI; 2007; p. 94).
} 
que é visível apenas em um hemisfério, mas resta uma questão: E para um observador na interseção destes dois hemisférios? O que ele poderá visualizar?

Para responder esta questão é interessante analisar, em termos de exemplo, a parcela da esfera celeste vista por um observador no hemisfério norte, assim como a parcela vista por um observador no hemisfério sul. Como sobre o equador a Latitude é zero, no Polo Norte $90^{\circ}$ e no Polo Sul $-90^{\circ}$ optou-se pela análise do céu noturno visto a partir de dois locais estratégicos, situados em posições simétricas com relação ao equador terrestre, e a uma cidade sobre a própria linha do equador. Tais localizações escolhidas são a cidade de Vermont, nos Estados Unidos da América (Latitude 44,5588 $\mathrm{N}$, Longitude $72,5778^{\circ} \mathrm{O}$ e Altitude $245 \mathrm{~m}$ ), Aisén, no Chile (Latitude $45,0070^{\circ} \mathrm{S}$, Longitude $72,5103^{\circ} \mathrm{O}$ e Altitude $82 \mathrm{~m}$ ) e Macapá, no Brasil (Latitude $0,0356^{\circ} \mathrm{N}$, Longitude $51,0705^{\circ} \mathrm{O}$ e Altitude $15 \mathrm{~m}$ ) (MAPA CELESTE INTERATIVO, 2016).

Ao analisar a Fig. 1 é possível observar que a Latitude sobre a linha do equador é convencionada como Latitude $0^{\circ}$ (zero) e as demais linhas, paralelas a esta, formam as demais Latitudes do globo, sendo aquelas acima do equador as Latitudes norte (por vezes representadas por valores positivos); enquanto que as Latitudes abaixo da linha equatorial são denominadas Latitudes sul (conhecidas como Latitudes de valores negativos). Verifica-se também que as Longitudes são medidas a partir do meridiano de Greenwich, sendo linhas com extremidades no Polo norte e no Polo sul, de modo que as linhas à direita de Greenwich são consideradas Longitudes leste (convencionadas com valores positivos), e à esquerda Longitudes oeste (com valores negativos) (IBGE, 1998, p.31).

A convenção de valores positivos e negativos para Latitudes e Longitudes se deve à origem deste sistema de coordenadas serem a linha do equador e o meridiano de Greenwich, para os quais a Latitude é $0^{\circ}$ e a Longitude é $0^{\circ}$, respectivamente.

Existem inúmeras fontes como livros, publicações técnicas, Atlas do céu e sites, que podem ser consultadas com a finalidade de estudar Cartas Celestes. Nesta proposta de atividade de ensino, optou-se por utilizar um site (MAPA CELESTE INTERATIVO, 2016) no qual foram geradas as Cartas Celestes analisadas; este site é organizado de forma simples e didática e sugere-se que o leitor o utilize para uma melhor compreensão e acompanhamento da análise efetuada - neste artigo foi inserida apenas uma Carta Celeste gerada para este estudo (Fig. 2) para evitar a poluição visual (já que foram analisadas 36 Cartas Celestes) e visando economia de espaço.

Iniciando a análise pela cidade de Vermont, foram geradas Cartas Celestes para as 22:00 h do dia 15 de cada mês do ano de 2016 que permitem comparar a parcela da esfera celeste observada.

Nas primeiras Cartas, pode-se verificar se a constelação do Cruzeiro do Sul estava ou não passível de observação. Sugere-se ao leitor optar por outra constelação austral mais próxima do Polo, caso esteja familiarizado com a posição relativa das constelações. Ao estudar 
cada Carta Celeste, é importante que seja observado, além das constelações visíveis, o movimento que as mesmas fazem no decorrer dos meses.

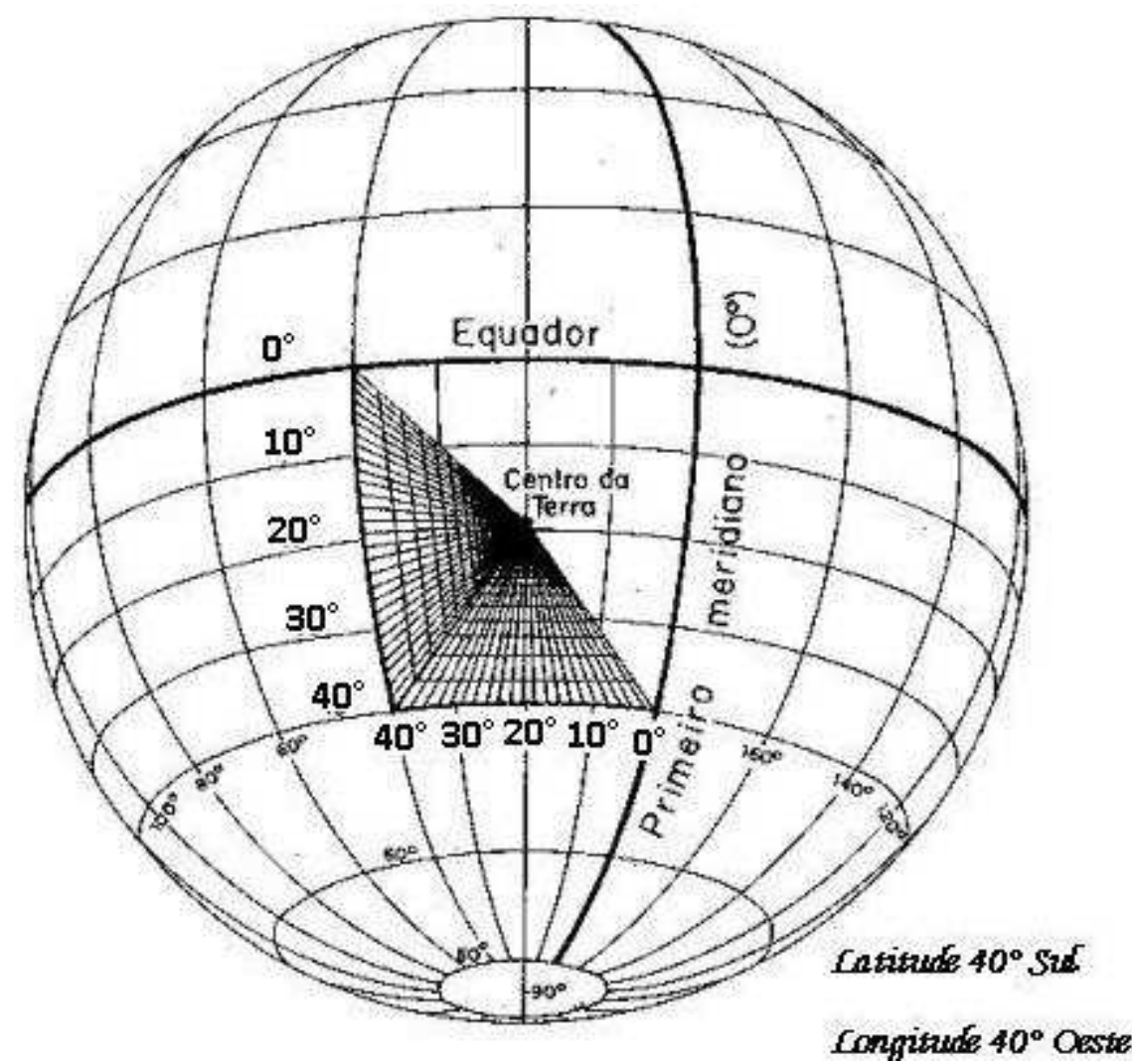

Fig. 1 -Representação das Latitudes e Longitudes na Terra. (IBGE; 1998, p. 31).

Nos primeiros meses de 2016, destaca-se a constelação Ursa Minor (Ursa Menor), que está entre as constelações de Draco, Cepheus, Cassiopeia e Girafa (Camelopardalis). Ao observar que durante os quatro primeiros meses ela faz um giro anti-horário, percebe-se que na verdade as demais também apresentam este giro aparente, bastando verificar que em fevereiro o Boieiro (Bootes) surge ao Nordeste e Andromeda já está desaparecendo ao Noroeste; ao passo que em março visualiza-se, em sua plenitude, Virgo, e logo em seguida, no mês de abril, Hercules desponta a Nordeste enquanto Aries e o Triangulum já sumiram do outro lado. O movimento denominado circumpolar indica que as constelações, mais próximas ao Polo, estão girando em torno do Polo Celeste Norte, o qual é quase coincidente com a estrela Polaris.

Em junho, observa-se o Triângulo de verão, formado pelas estrelas Vega (na constelação de Lyra), Altair (na constelação de Aquila) e Deneb (na constelação de Cygnus). Este triângulo e as demais constelações seguem seu movimento, em torno do Polo, revelando novas constelações e ocultando outras; porém começa-se a perceber que algumas constelações continuam visíveis desde janeiro, como Ursa Minor e Major, Cepheus, Cassiopeia e Draco. 
Ao finalizar o ano, pode-se ver que muitas das constelações catalogadas não foram observadas, e em contrapartida outras estiveram visíveis durante todo o ano, podendo-se vislumbrar seu movimento completo em torno do Polo Celeste Norte.

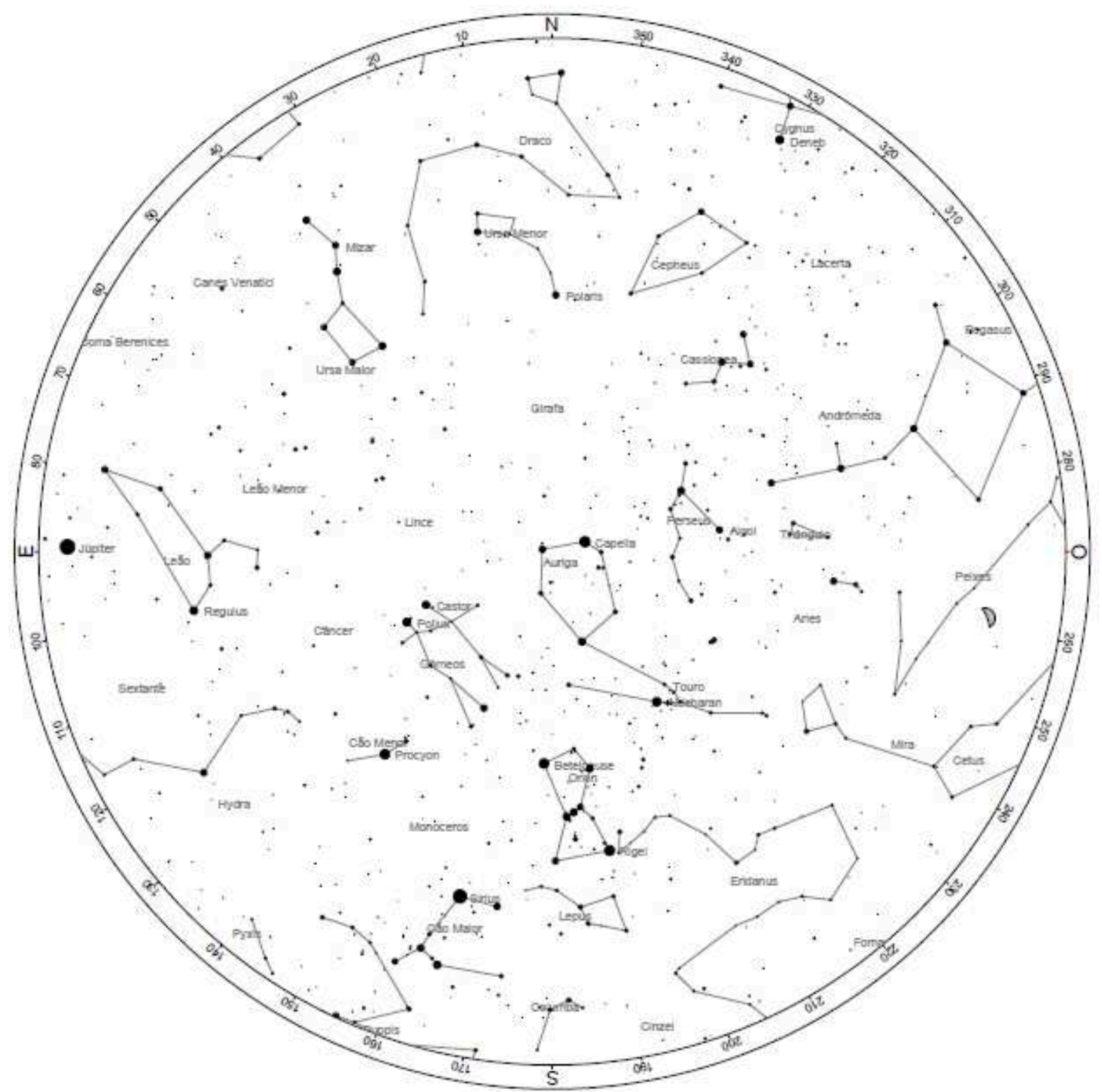

Fig. 2 - Carta Celeste para o dia 15 de janeiro de 2016 para a cidade de Vermont, nos EUA (MAPA CELESTE INTERATIVO, 2016).

Nesta primeira análise, evidencia-se uma considerável quantidade de 25 constelações inobserváveis para a Latitude considerada, enquanto que 63 são visíveis no decorrer do ano. Ao analisarem-se as Cartas Celestes, percebe-se ainda que no decorrer dos meses as constelações visíveis vão se diversificando. A respeito desse aspecto, Mourão (2004, p.15) comenta:

Tal deslocamento é o movimento de rotação, movimento aparente diurno provocado pela rotação terrestre em torno de seu eixo. Observando sempre num mesmo lugar, 
o observador verá que uma mesma estrela aparece e desaparece todos os dias em um mesmo ponto do horizonte... todavia de um dia para o outro, o nosso observador irá notar que uma estrela aparece e desaparece quatro minutos mais cedo... por esse motivo, se observarmos o céu sempre à mesma hora, veremos que seu aspecto se modificará: algumas estrelas deixarão de ser vistas e outras surgirão.

Prosseguindo a análise, agora para uma localização aproximada de $45^{\circ} \mathrm{Sul}$, foi escolhida a cidade de Aisén, no Chile (Latitude $45,0070^{\circ} \mathrm{S}$, Longitude $72,5103^{\circ} \mathrm{O}$ e Altitude 82 m). Para esta cidade, as datas e horários utilizados para gerar as Cartas Celestes foram mantidos.

Da mesma forma como ocorreu na análise das Cartas Celestes de 2016 para a cidade de Vermont, aqui se verifica também que as constelações no decorrer dos meses de janeiro, fevereiro, março e abril estão realizando um movimento que apresenta indícios de ocorrer em volta de certo ponto, mas, neste caso, tal ponto está na parte central e inferior à Carta, com a ressalva de que o sentido de giro é contrário ao do caso anterior, ou seja, é no sentido horário. Este ponto é denominado Polo Celeste Sul e não possui uma estrela que o marca aparentemente, como no caso de Polaris no hemisfério norte. Este movimento também é denominado circumpolar.

Em maio, com o surgimento da constelação de Sagitarius, uma parcela rica em objetos dignos de observação astronômica fica disponível para amantes do céu noturno. Tornamse notáveis constelações como Camaleão (Chamaleon), Volans, Mensa, Tucana, Octante (Octans) e Apus, entre outras, que continuam visíveis desde o início do ano e, diferentemente da cidade do hemisfério norte estudada, que tem Polaris marcando o Polo, tais constelações fazem um giro em torno de um ponto, o Polo Celeste Sul.

Aqui é observado um mesmo aspecto verificado na observação celeste da cidade de Vermont $\mathrm{a} \sim 45^{\circ} \mathrm{N}$ de Latitude, porém com características diferentes. Este aspecto está relacionado com a questão de que mais uma vez apenas uma parcela das constelações catalogadas é visível, sendo que muitas dessas não são visíveis no caso anterior, e outras são coincidentes com as vistas de Vermont. Pode-se vislumbrar o movimento completo de algumas constelações em torno do Polo Celeste Sul.

Ao se comparar esta análise e a anterior, é evidenciado que algumas constelações observáveis em uma, não são na outra. Outra característica marcante é que para o observador no hemisfério sul existe uma quantidade superior de constelações observáveis, já que, neste caso, apenas 8 constelações não estão visíveis e, em contrapartida, 80 são passíveis de observação durante o ano.

Esta diferença na quantidade de constelações observáveis entre as Latitudes aproximadas de $45^{\circ} \mathrm{N}$ e $45^{\circ} \mathrm{S}$ está relacionada com a quantidade de constelações que foram batizadas nestes dois hemisférios, isto é, quando se padronizou figuras que se formariam ao conectar-se, de forma aparente a partir da Terra, diferentes estrelas. Este processo acabou formando um número maior de figuras na medida em que se aproxima do Polo Celeste Sul. Tal evidên- 
cia é constatada ao se verificar o céu para o Polo Sul e para o Polo Norte (REES, 2008a, p. 350-351). A Fig. 3 fornece subsídio para comparação visual da quantidade de constelações nos dois hemisférios.
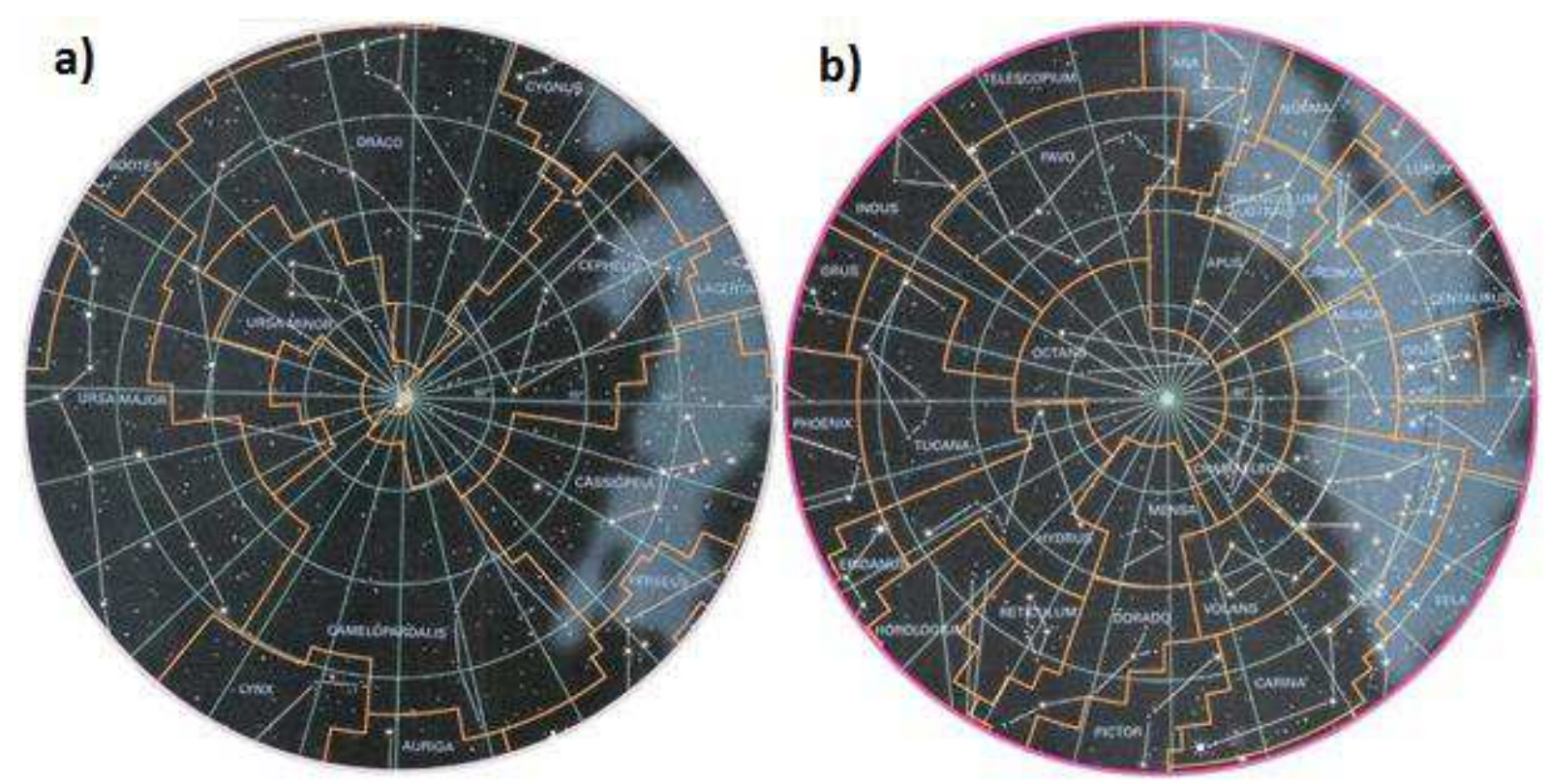

Fig. 3 - a) O céu polar boreal. b) O céu polar austral (REES, 2008a, p. 350-351).

Comparando as Fig. 3a e 3b, verifica-se que a partir do Polo Celeste Sul há uma quantidade maior de constelações visíveis com relação ao Polo Celeste Norte. Observa-se também que nas duas figuras existem círculos concêntricos, que representam os movimentos aparentes das constelações em torno do ponto central, os Polos. De acordo com Mourão (2004, p. 15):

O ponto ao redor do qual as estrelas descrevem círculos concêntricos constitui o ponto em que o eixo da Terra prolongado perfuraria a esfera celeste... Um observador nos Polos terrestres, seja no norte ou no sul, veria as estrelas girando paralelamente ao horizonte, continuamente, e nunca nascerem ou se porem no horizonte.

Para um observador à Latitude zero, todas as constelações catalogadas são visíveis, ou seja, há disponibilidade de ampla diversidade de possibilidades observacionais neste ponto de referencia, tornando-se assim um observatório natural privilegiado. Eis um detalhe que geralmente passa despercebido por muitos observadores do céu noturno. A relação entre a parte visível da esfera celeste e a latitude de onde a mesma é vislumbrada é explicada por Rees (2008b, p. 60):

Um observador na Terra pode, no máximo, ver somente metade do céu em cada instante ... para um observador em um dos Polos celestes, uma metade específica da esfera celeste sempre estará acima do horizonte, e a outra sempre abaixo. Para ob- 
servadores em outras latitudes a rotação da Terra continuamente traz novas partes da esfera celeste para a vista e oculta outras... Um observador no equador verá toda a esfera celeste se aguardar tempo suficiente.

O movimento diário aparente das estrelas também é evidenciado por Mourão, o qual descreve que para observadores nos Polos terrestres, seja no norte ou no sul, as estrelas giram paralelas ao horizonte (em um movimento denominado circumpolar) sem nunca nascerem e nem se porem no horizonte; enquanto que no equador terrestre, os observadores podem ver que as estrelas nascem e se põem perpendicularmente no horizonte (MOURÃO, 2004, p. 15).

Para completar o ciclo de análise de Cartas Celestes necessário para se obter a relação entre posição geográfica e parcela visível da esfera celeste, propõem-se as Cartas referentes à cidade de Macapá (Latitude $0,0356^{\circ} \mathrm{N}$, Longitude $51,0705^{\circ} \mathrm{O}$ e Altitude $15 \mathrm{~m}$ ), no Brasil, para o ano de 2016, com as mesmas datas e horários que foram geradas para as Latitudes norte e sul.

Foi notado que em janeiro estava surgindo na posição Leste a constelação de Hydra, e na sequência em fevereiro, março e abril sua trajetória seguiu praticamente em linha reta, cortando a esfera celeste em direção ao Oeste poente. Ao verificar as demais constelações presentes na Carta Celeste de janeiro, observa-se que elas seguem nos meses seguintes, em linha reta, a mesma trajetória de Leste à Oeste; exceto as constelações próximas aos Polos, cuja trajetória é um arco, já que os Polos Celestes Norte e Sul se encontram no horizonte norte e sul, respectivamente.

No período e Latitude considerados, foi verificado que em meio ano já havia sido possível a observação de $~ 92 \%$ de todas as constelações catalogadas da esfera celeste; e em julho de 2016 as sete que faltavam despontam no horizonte completando o conjunto das 88 constelações catalogadas antes mesmo de se completar um ano terrestre.

Na verdade, em uma única noite um observador à Latitude zero pode apreciar quase todas as constelações, o que é impossibilitado apenas pelos raios do Sol no entardecer e no amanhecer; restando ao observador a possibilidade de vislumbrar a esfera celeste completa, com todo seu esplendor no decorrer de um ano terrestre, um exercício de paciência e perseverança que é compensado pela beleza gratuita oferecida pelo céu.

\section{II.1 Construindo um Planisfério para a Latitude zero}

A abordagem feita até aqui permite compreender que em cada Latitude do planeta se visualiza uma parte distinta da esfera celeste, sendo que a Latitude zero representa uma posição privilegiada na qual um observador pode visualizar todas as constelações catalogadas. Albrecht e Voelzke (2010) afirmaram que apesar de os temas em Astronomia serem recomendados nos documentos oficiais, eles praticamente não são ensinados em escolas de nível Fundamental e Médio. São necessários, portanto, trabalhos que forneçam suporte ao professor de Física, ou outra disciplina afim, para que ele adquira ou complemente esse conhecimento e possa propaga-lo para a população em geral. Langhi e Nardi (2012) defendem que a formação 
inicial e continuada dos professores contemple a abordagem de tópicos de Astronomia com vistas a proporcionar autonomia em sua atividade docente. Porém, em termos didáticos, precisa-se de ferramentas que auxiliem essa popularização, tais como a utilização de softwares de Astronomia, Anuários astronômicos, Cartas Celestes ou Planisférios.

Essas iniciativas favorecem a superação de eventuais lacunas no processo de formação docente, aspecto também destacado por Langhi e Vilaça (2015, p. 9), os quais apontam para a importância de se oferecer aos professores "fontes, conteúdos, propostas de atividades, sugestões metodológicas e didáticas", além de relatos de experiências. Com isso é possível valorizar a Astronomia no contexto da educação básica, em linha com o que asseveram Silva, Araújo e Voelzke (2014, p. 20) ao apontarem que:

Por não ser comum a cobrança de conhecimentos de Astronomia nos vestibulares, pouco valor se tem dado para esses conteúdos; situação agravada pelo fato de muitos professores não apresentarem domínio satisfatório sobre os temas que compõem essa área de conhecimento.

Para servir de suporte ao ensino de Física e ser utilizado com mais facilidade pelo sistema educacional, dispensando o uso de salas de informática, não disponíveis em todas as escolas públicas, é proposta a montagem de um Planisfério para a Latitude zero. Um Planisfério é um dispositivo pelo qual se representa o movimento aparente da esfera celeste sobre uma superfície plana para certa hora, dia e mês, para uma determinada Latitude, no caso deste trabalho específico, para a Latitude zero.

Na montagem do Planisfério Equatorial, serão utilizadas duas Cartas Celestes, sendo uma para o hemisfério norte e outra para o hemisfério sul, e duas partes denominadas "máscaras", sendo uma para cobrir cada Carta Celeste, ou seja, uma possibilita reconhecer o céu olhando para o norte, enquanto a outra se destina ao reconhecimento do céu olhando para o sul.

Na Fig. 4, tem-se a Carta Celeste contendo o céu para o hemisfério norte, com as nomenclaturas e as linhas das constelações boreais. O Polo Celeste Norte está representado no centro da imagem através de uma pequena cruz (em uma das extremidades da linha que demarca a constelação da Ursa Menor), e a identificação das principais estrelas tem destaque pela fonte de cor violeta. Além disso, a Carta está sendo circundada por uma escala contendo os meses de janeiro a dezembro (um ano terrestre) com os dias espaçados simetricamente de 5 em 5, aspecto essencial para os alinhamentos que serão descritos adiante.

Esta imagem deve ser impressa para a montagem do Planisfério - o leitor pode inclusive imprimir a página inteira para recortar a Carta Celeste posteriormente. Caso se pretenda visualizar o céu a partir de uma Latitude diferente da Latitude zero sugere-se a utilização das imagens contidas no endereço eletrônico da Universidade Federal do Rio Grande do Sul que está incluído nas referências bibliográficas ao final do artigo, assim como se pode seguir o roteiro de montagem que o site disponibiliza (SARAIVA, 2017). 


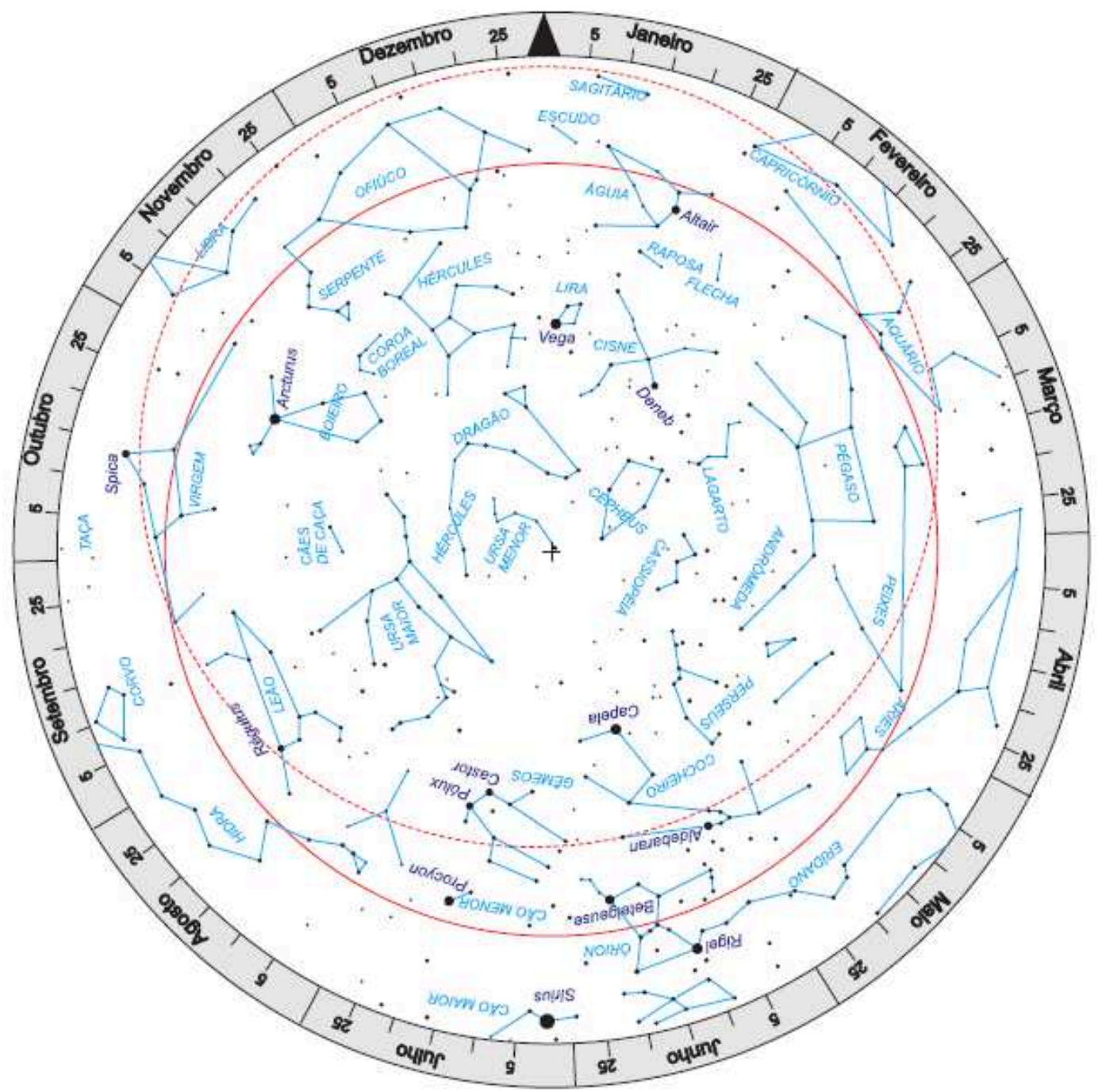

Fig. 4 - Carta celeste para o norte fim montagem de Planisfério (SARAIVA, 2017).

A Carta Celeste da Fig. 4 demonstra todo o céu boreal e para que seja possível a identificação da parcela do céu visível deve-se ocultar uma parte (a não ser que o observador esteja localizado na Latitude $90^{\circ}$, no Polo Norte, pois neste caso bastaria a Fig. 4 para que o observador pudesse identificar as constelações vísiveis, dispensando desta forma o restante do Planisfério). Com este propósito tem-se a segunda parte do Planisfério que é sua parte móvel, conhecida como "máscara", a qual está representada na Fig. 5 para o hemisfério norte, e que possui uma abertura - a parte branca da imagem - que precisa ser destacada para servir de "janela visual" para o observador.

Assim como no caso da Carta Celeste Norte, a "máscara norte" deverá ser impressa e recortada para ser agregada ao conjunto do Planisfério. A impressão pode ser feita como a da Fig. 4, imprindo-se a página inteira em que a imagem está inserida e recortá-la pela borda exterior. É importante que todas as imagens impressas para compor o Planisfério para Latitude zero sejam feitas com alta qualidade de imagem para que seja possível a identificação de seus elementos sem muita dificuldade. 


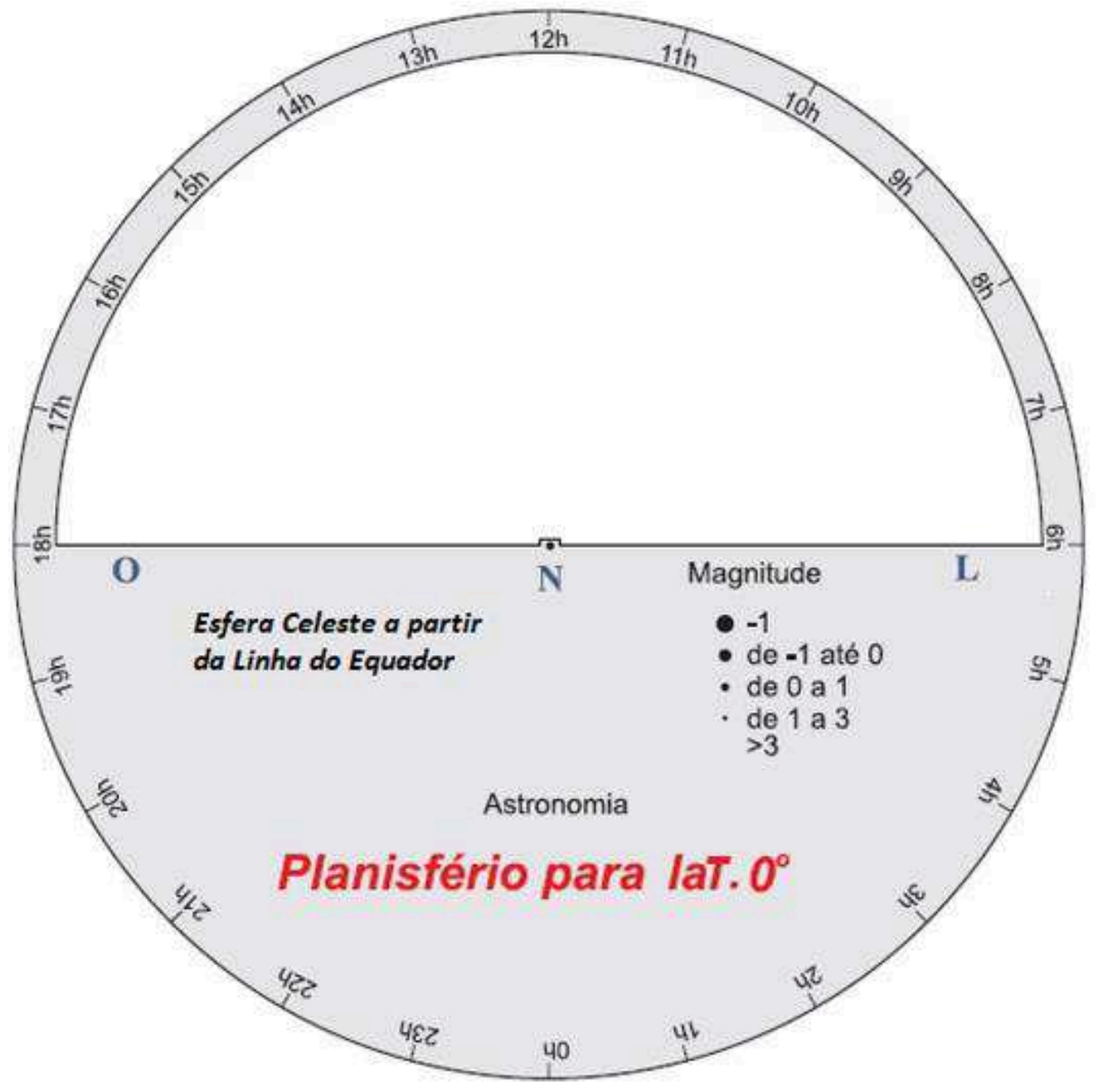

Fig. 5 - "Máscara" Norte - Parte móvel do Planisfério para cobrir parcialmente a Carta celeste para o norte deixando visível apenas a parte permitida sujeita a data e horário selecionados pelo alinhamento.

A Fig. 6 traz a representação celeste do hemisfério austral através da Carta Celeste para o sul; observa-se que ela possui as mesmas características estruturais da Carta Celeste para o norte, com a diferença de que as constelações observadas são distintas. Como a maior parcela territorial do Brasil está no hemisfério sul, esta Carta apresenta em termos gerais mais constelações conhecidas pelo brasileiro do que a boreal, como exemplo cita-se Escorpião e o Cruzeiro do Sul.

Repete-se aqui as orientações anteriores com relação à impressão da página e recorte da Carta Celeste em questão, pois se as imagens tiverem suas dimensões editadas, isto provavelmente comprometerá os passos que virão adiante, reduzindo ou anulando o funcionamento adequado do Planisfério. 


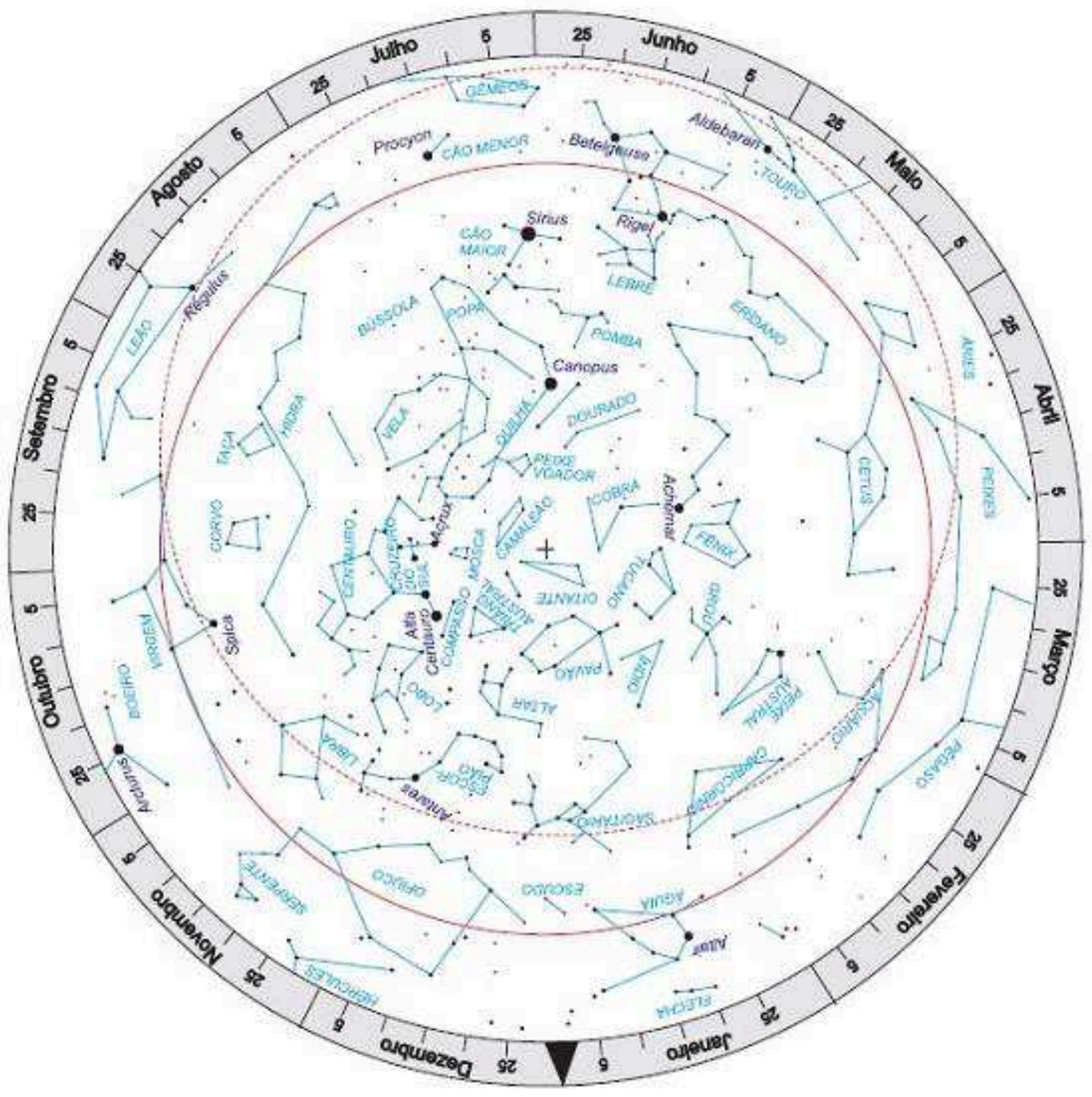

Fig. 6-Carta celeste para o sul fim montagem de Planisfério (SARAIVA, 2017).

A Fig. 7 contém a "máscara" para o sul e completa as partes do Planisfério que necessitam de impressão. É a sua segunda parte móvel, com uma "janela visual" que permitirá as observações das constelações austrais.

Observe que, na borda das "máscaras" norte e sul, há uma escala numérica de 0 (zero) a 23 h que deverá ser alinhada com a data (contida na Carta Celeste Norte e Sul) em que o observador pretende efetuar observação.

É importante observar que na Fig. 7 existe um pequeno ressalto próximo da marcação "S" (de Polo Sul) com um ponto em seu centro, onde irá passar o eixo de interligação entre as partes do Planisfério e que permitirá o movimento rotacional do mesmo; no momento de destacar a parte branca da "máscara" deve-se fazê-lo com sutileza para não cortar tal ressalto. Na Fig. 5 (que contém a "máscara" para o norte), também possui um ressalto como esse, e o cuidado deve ser o mesmo para não o desperdiçar. 


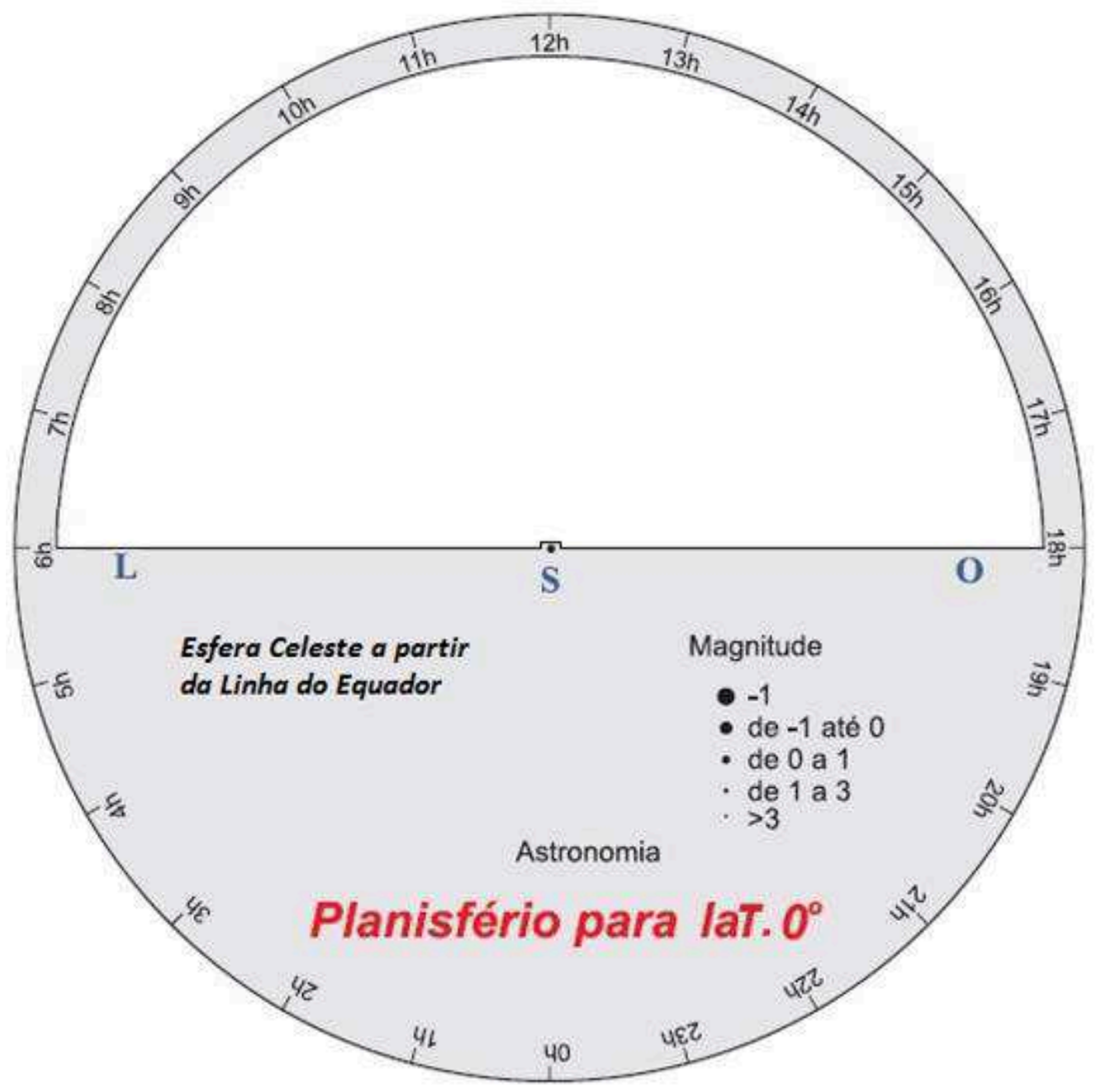

Fig. 7 - "Máscara” Sul - Parte móvel do Planisfério para cobrir parcialmente a Carta celeste para o sul deixando visível apenas a parte permitida sujeita a data e horário selecionados pelo alinhamento.

A primeira ação para montagem do Planisfério é a impressão das Fig. 4, 5, 6 e 7 (conforme orientações anteriores) e, após isso, reúne-se o restante dos materiais que serão utilizados e que estão presentes na Fig. 8A, dispostos a partir da esquerda na seguinte ordem: as 04 impressões, 01 tubo de cola para papel, 01 prego, 01 borracha, 01 estilete, 01 tesoura e 01 folha de papel Paraná recortada em 3 partes de tamanho A4 cada.

Após a reunião de todo material que será utilizado, inicia-se a construção do Planisfério recortando-se as Cartas Celestes Norte e Sul e suas partes móveis utilizando-se a tesoura ou o estilete. A parte branca das "máscaras" deve ser destacada, com o cuidado de manter o ressalto que marca Polo Celeste, tanto norte quanto o sul, e para tal é mais fácil a execução com o auxílio do estilete. 


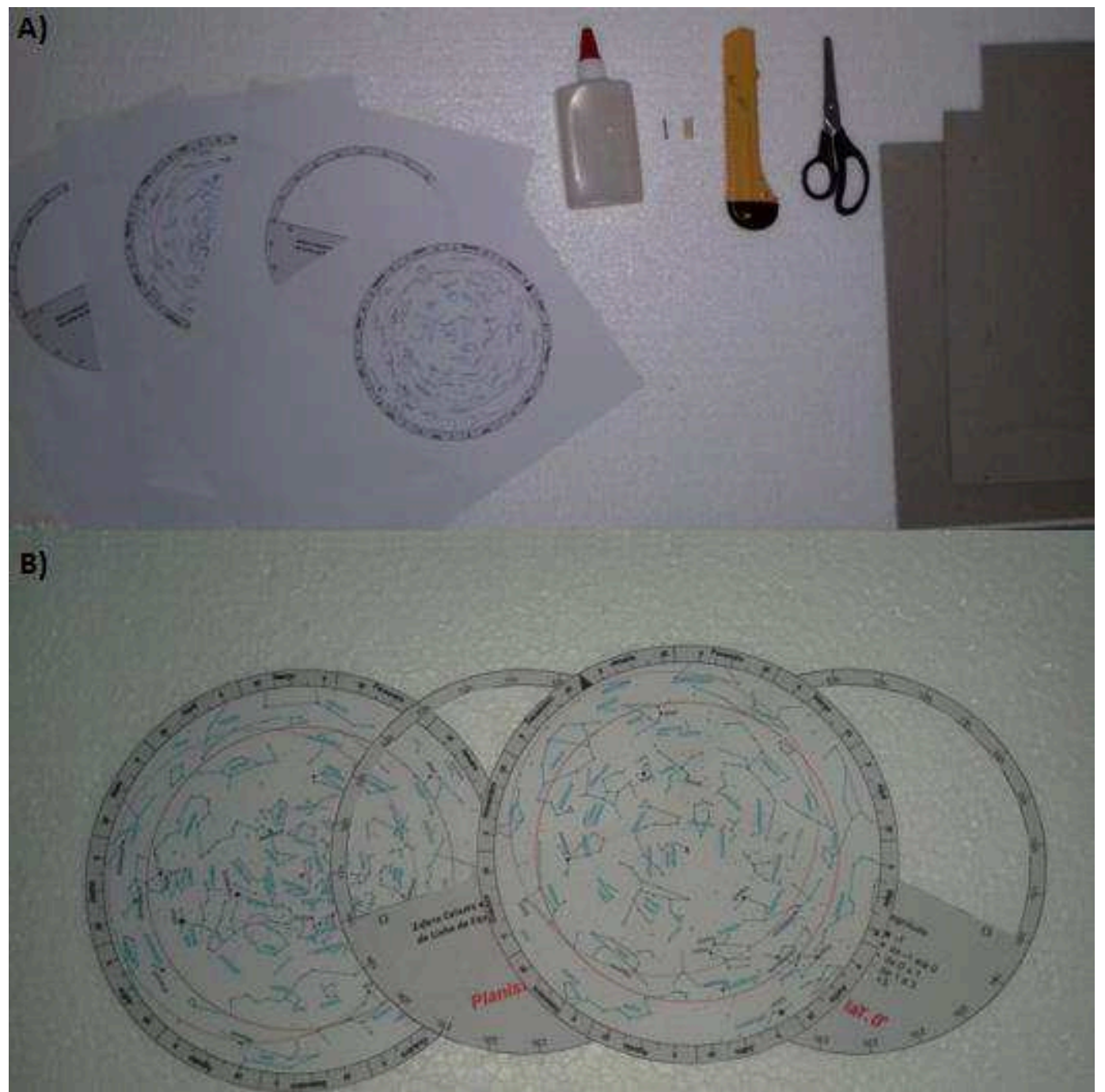

Fig. 8 - A) Material para montagem do Planisfério para latitude zero. B) Cartas Celestes e respectivas "máscaras" já recortadas.

A Fig. 8B exibe como deve ficar o resultado das partes do Planisfério já recortadas. Atenção especial à parte interna das "máscaras" norte e sul que já foram recortadas e retiradas deixando a "janela visual" livre para observação.

O passo seguinte consiste em utilizar a cola para colar uma das Cartas Celestes em um dos pedaços de papel Paraná - didaticamente pode-se iniciar este procedimento para a Carta Celeste Norte. Depois de colado no papel Paraná recorta-se utilizando a tesoura, conforme mostrado na Fig. 9A. Na sequência deve-se colar neste verso a outra Carta Celeste neste caso a do sul - tendo-se o cuidado de fazer coincidir nos dois lados a seta triangular contida na escala dos meses (situada entre os meses dezembro e janeiro). 


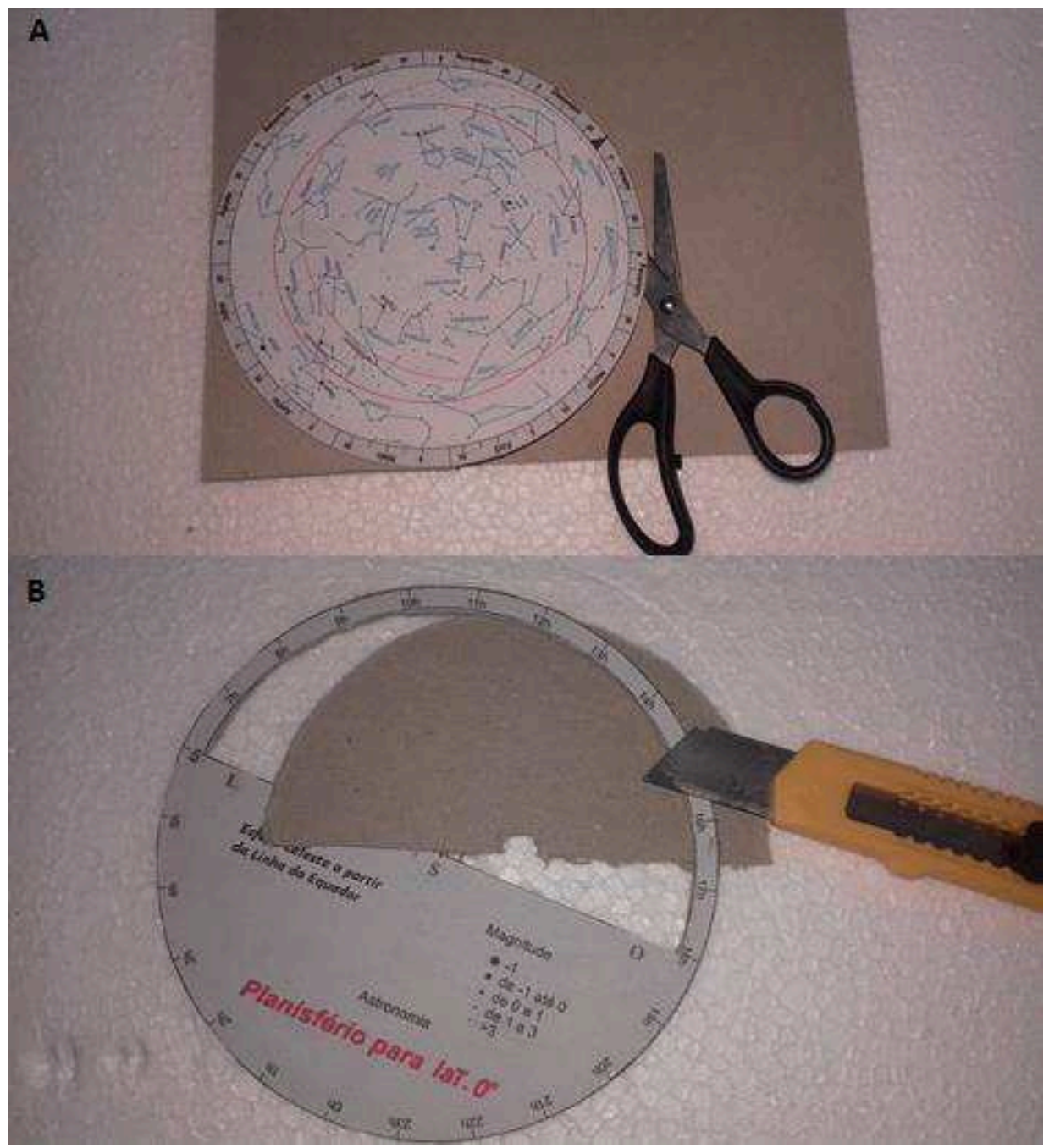

Fig. 9 - A) Carta Celeste, já colada no papel Paraná, sendo recortada. B) "Máscara” para o sul, já colada no papel Paraná e recortada, tendo sua parte interna sendo destacada.

Na Fig. 9B, evidencia-se o trabalho com as partes móveis do Planisfério. Cola-se cada uma das "máscaras" em um pedaço de papel Paraná e depois se recorta cada uma com a tesoura. A continuação se dá com o auxílio do estilete e destacando-se a parte interna de cada máscara (de acordo com a Fig. 9B).

Para o próximo passo, deve-se colocar a "máscara" para o sul sobre a Carta Celeste Sul e a "máscara" para o norte sobre a Carta Celeste Norte e usa-se o prego (que pode ser substituído por ilhós, parafuso para pasta plástica ou similar) furando-se e unindo-se as três partes pelo ponto central demarcado por um ponto próximo ao "N" e ao "S". No lado oposto, usa-se a borracha para cobrir a parte pontiaguda do prego visando com isso evitar acidentes, sendo que esta pode ser substituída por algum material similar. Opcionalmente, pode-se usar uma fita adesiva para prender uma "máscara" à outra - exatamente pela posição de $0 \mathrm{~h}$ - para 
movê-las juntas; porém, sugere-se a dispensa deste procedimento e que se façam os alinhamentos necessários para cada lado do Planisfério que se deseje utilizar.

Na Fig. 10, tem-se a imagem dos dois lados do Planisfério para Latitude zero pronto para ser utilizado.

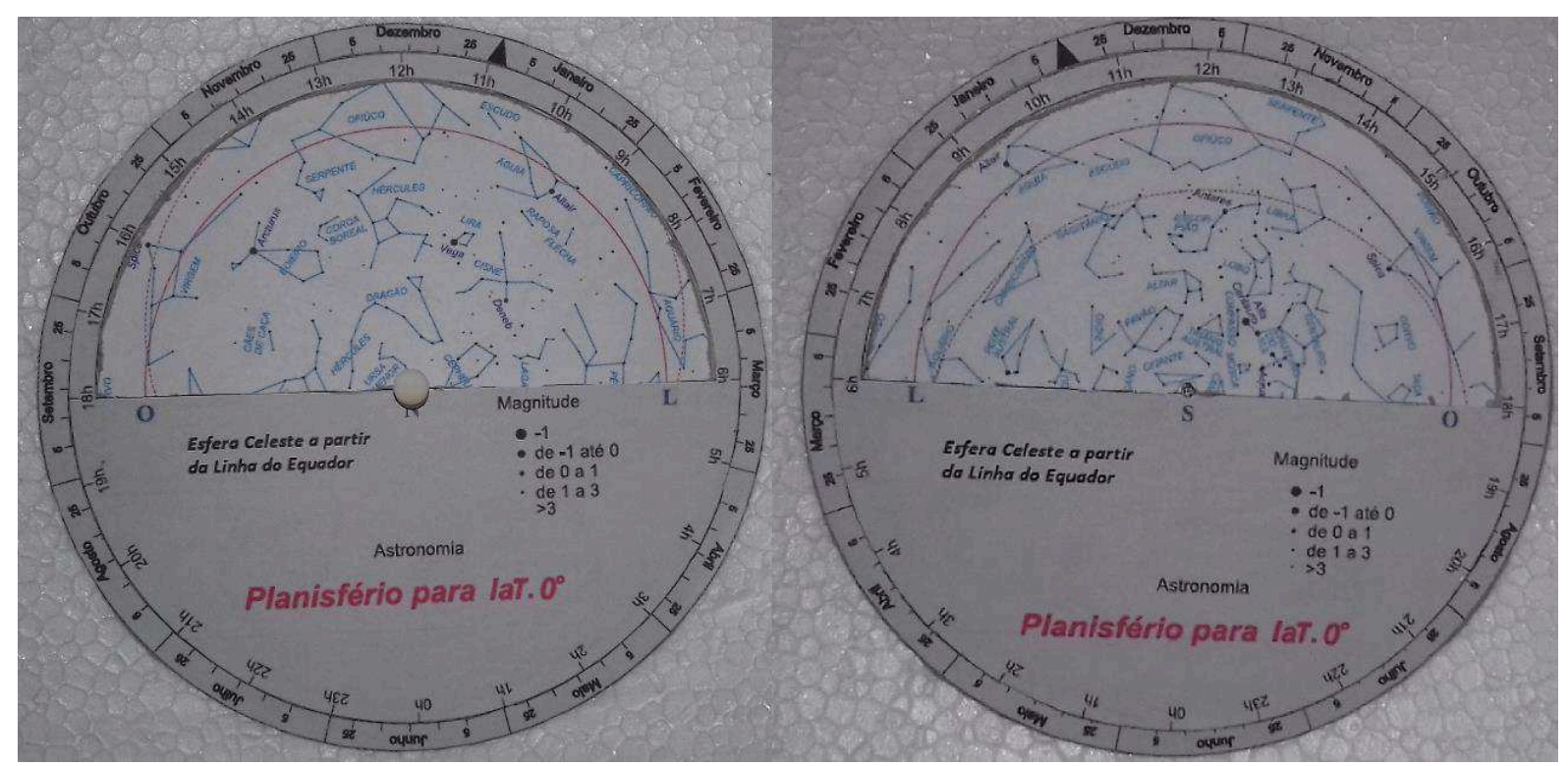

Fig. 10 - Planisfério para Latitude zero (imagem dos dois lados).

Com o Planisfério pronto, basta que o observador faça o alinhamento do horário com a data corrente para então apreciar, através da "janela”, o céu visível neste momento para um referencial sobre a linha do equador. É importante salientar que este Planisfério foi desenvolvido especificamente para um observador localizado na Latitude zero, caso a localização seja em outra Latitude é necessária a utilização de um Planisfério construído para uma Latitude mais próxima da local.

\section{O equinócio observado da Linha do Equador}

A análise do movimento aparente do Sol cruzando o céu é feita há muito tempo. Voelzke e Araújo observam que: “[...] o entendimento dos fenômenos celestes e a relação destes com o que acontece em nosso próprio planeta Terra foram sendo ampliados, permitindo que compreendêssemos melhor a dinâmica dos corpos celestes" (VOELZKE; ARAÚJO, 2010, p. 76). A inteligência humana lhe permite além de observar um fenômeno, questioná-lo para compreender suas causas. Este fato remonta a um passado distante, onde o homem já tentava compreender porque o Sol percorre seu caminho pelo zodíaco. O escritor Hart-Davis fornece um belo exemplo ao abordar a importância das estações no mundo antigo (HARTDAVIS, 2010, p. 24): 
As estações críticas de caça e colheita passaram a ser reguladas por um calendário solar quando se reconheceu que o movimento do Sol era a causa do ciclo das estações. Essa influência do astro induziu à crença de que estrelas e planetas deveriam ser observados e adorados.

As Estações climáticas são basicamente divididas em quatro, ou seja, primavera, verão, outono e inverno. É salutar evidenciar que existem dois fatores primordiais que determinam a diferença entre estas estações, que são o movimento relativo entre a Terra e o Sol e a inclinação do eixo de rotação terrestre. Um exemplo da influência destes fatores como primordiais na determinação das estações climáticas é citado por Capozzoli ao se referir sobre o Equinócio de primavera para o hemisfério sul (CAPOZZOLI, 2011, p. 21):

O fato mais significativo de setembro é o equinócio de primavera... quando o Sol cruza o equador celeste em seu movimento aparente em direção ao hemisfério celeste sul. Aqui é importante considerar que estamos nos referindo ao "movimento aparente" do Sol e não a um movimento próprio, porque esse deslocamento resulta da inclinação do eixo de rotação da Terra que produz as estações do ano.

A influência da inclinação do eixo de rotação da Terra na determinação das estações do ano pode ser identificada pela observação da Fig. 11 a seguir e que permite observar que a inclinação do eixo do planeta Terra na situação específica favorece um aquecimento mais intenso no hemisfério sul, sendo este aumento de temperatura no verão decorrente da mudança do ângulo de incidência dos raios de luz.

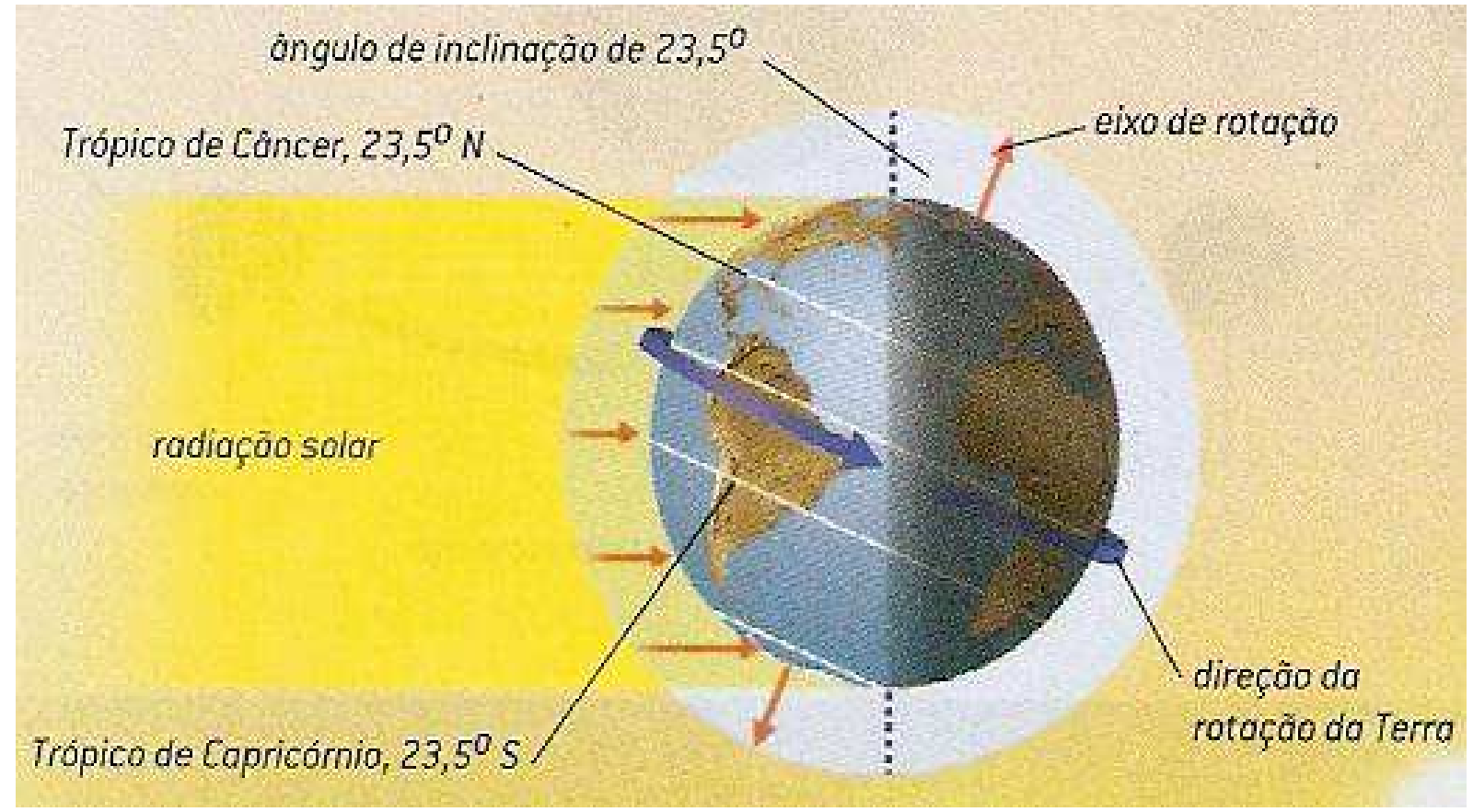

Fig. 11 - Efeito da inclinação do eixo de rotação da Terra (REES, 2008b, p. 63). 
Este fato, aliado à questão de que neste período os dias são mais longos que as noites, tende a ocasionar uma maior elevação da temperatura da superfície terrestre no hemisfério sul, correspondendo à estação climática do verão, conhecida pelas propagandas turísticas de veraneio. Ainda na Fig. 11, porém observando o hemisfério norte, verifica-se o caso contrário, provocando nesta região um aquecimento menos intenso que no hemisfério oposto. Simultaneamente a este fato destaca-se que na região imersa na escuridão as noites são mais longas e, consequentemente, os dias mais curtos, o que significa menos tempo de exposição ao Sol por dia, proporcionando uma temperatura mais baixa que no hemisfério sul. Esta situação define a estação climática denominada de inverno.

Um rápido estudo dessa figura não deixa dúvidas quanto à duração do dia e da noite nas estações de inverno e verão para os dois hemisférios. Mas o que ocorre quanto a um observador sobre a linha do equador? Qual a diferença entre a duração dos dias e das noites nessas duas estações climáticas? Apesar de ser uma questão simples de ser analisada, não possui uma resposta muito propagada. Mais uma vez, recorre-se à Fig. 11, onde observando a linha do equador percebe-se que metade dela está sendo iluminada pelo Sol, enquanto exatamente a outra metade está imersa na escuridão da noite. Portanto, é fácil concluir que as durações do dia e da noite sobre a Latitude zero são iguais, fato este que se estende a qualquer período do ano, seja ele primavera, verão, outono ou inverno. Esta constatação a respeito da simetria entre as durações do dia e da noite é corroborada por Flammarion (1908, p. 121):

[...] a duração do dia varia não só segundo as estações, mas também com a latitude... No equador, tem-se constantemente doze horas de dia e doze horas de noite. Indo do Equador para os Polos, a diferença da duração da iluminação solar do dia mais longo para o dia mais curto, aumentam gradualmente (Grafia original).

Entre o verão e o inverno existem as estações denominadas de primavera e outono. A primeira é reconhecida, principalmente, pelo reflorescimento nos campos, após o período de inverno onde, de forma geral, a paisagem campestre é de aspecto menos colorido. Enquanto que o outono, o qual segue a estação do verão, ocasiona certo alívio na temperatura, caracterizando-se como um período transitório entre o verão e o inverno. Com a finalidade de compreender mais concisamente as especificidades inerentes a cada posição relativa do sistema Terra-Sol, é importante que se analise a Fig. 12, disposta a seguir.

Como as posições relativas entre a Terra e o Sol, definindo as estações de inverno e verão, já foram discutidas, é mister que se façam alguns comentários sobre como tal posicionamento caracteriza as estações intermediárias, primavera e outono. A Fig. 12 evidencia que no momento em que se atinge a primavera no hemisfério norte (outono no hemisfério sul) o planeta será iluminado por igual (desconsiderando-se a diferença decorrida da curvatura da Terra). Devido a tal igualdade, os dias e as noites têm a mesma duração, globalmente.

Cabe ainda destacar que a insolação é maior na latitude zero justamente nos equinócios. Neste sentido, este local diferencia-se do resto do globo pelo fato de receber a menor insolação do ano durante o próprio solstício de verão e também durante o solstício de inverno. 
Este fenômeno é relevante e merece ser discutido na educação escolar, permitindo desfazer a associação de que é sempre no verão que são encontradas as temperaturas mais altas do ano para todo o território brasileiro, o que não é verdadeiro.
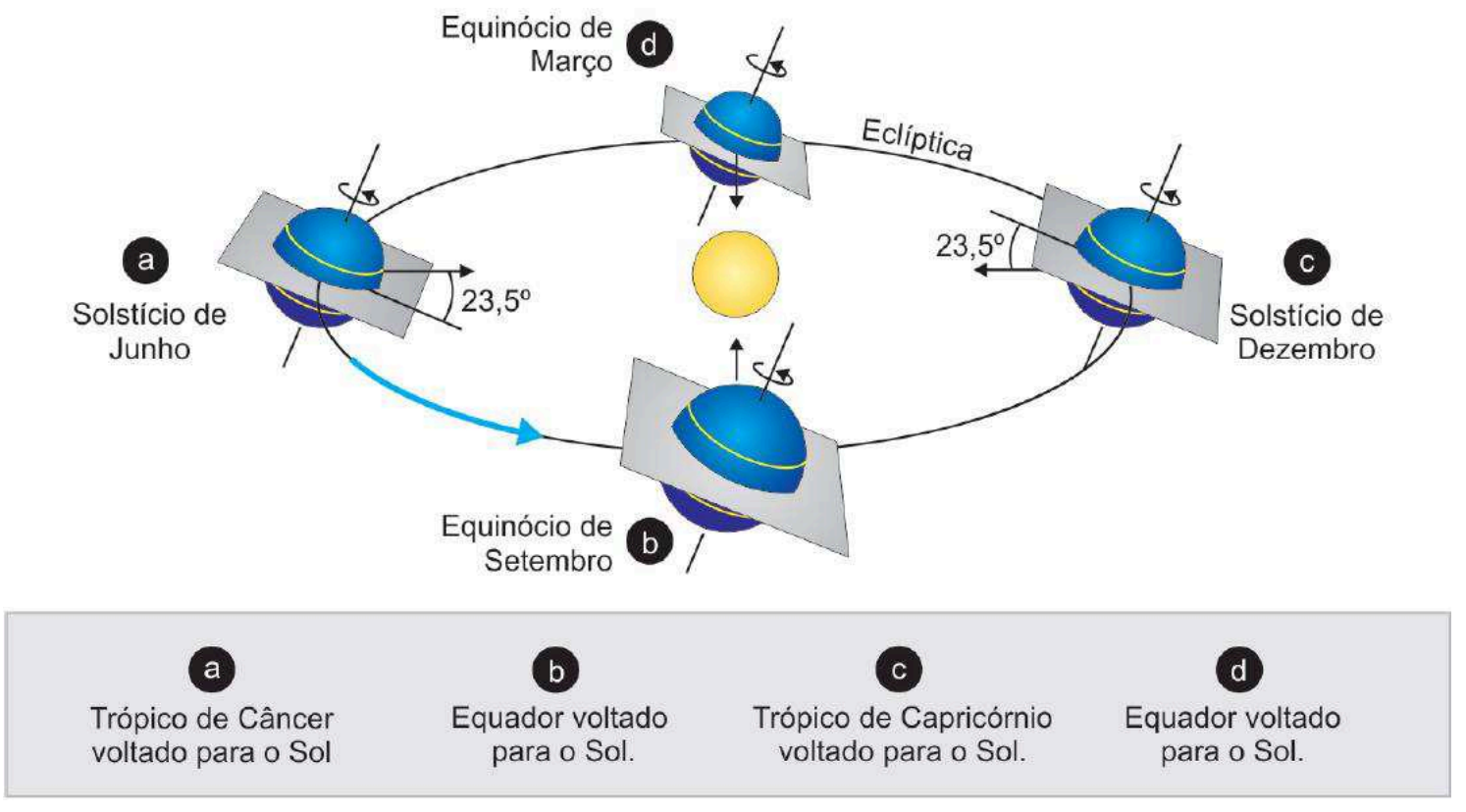

Fig. 12 - Posições relativas do sistema Terra-Sol durante uma revolução terrestre completa ao redor do Sol (OLIVEIRA FILHO; SARAIVA, 2014, p. 47).

Quando ocorre a transição de uma estação para outra, existem momentos especiais denominados Solstícios e Equinócios. Tais momentos são contemplados na Fig. 12. Mourão (1987, p. 749) nos fornece a definição de Solstício:

[...] solstício. Época em que o Sol no seu movimento aparente na esfera celeste atinge seu maior afastamento do equador. Existem duas épocas no ano em que ocorrem os solstícios: uma delas é em 22 ou 23 de dezembro, quando o Sol atinge o seu maior afastamento do equador, na direção do Polo sul, e a outra é em 22 ou 23 de junho, na direção do Polo norte. No hemisfério sul, a primeira data se denomina solstício de verão e a segunda o solstício de inverno; todavia, como as estações são opostas nos dois hemisférios, estas denominações se invertem no hemisfério norte.

Uma forma tradicional, e até didática, de se verificar tais afastamentos máximos é com a utilização de um gnomon, que nada mais é que uma vara fincada perpendicularmente no solo. O procedimento consiste em medir a sombra do gnomon durante o meio dia "verdadeiro" (quando o Sol passa pelo meridiano local). A medida da sombra fornecerá elementos para identificar os Solstícios, embora a conclusão sobre se este é de Verão ou de Inverno dependerá da latitude do observador (AFONSO, 1996, p. 154). 
Para pontos que se iniciam a Primavera e Outono, isto é, os Equinócios, Mourão (1987, p. 269) também traz a seguinte definição:

\begin{abstract}
[...] equinócio. 1. Qualquer das duas interseções do círculo da eclíptica com o círculo do equador celeste, a saber: equinócio da primavera, ou ponto vernal, e equinócio do outono, ou ponto de Libra. 2. Instante em que o Sol, no seu movimento anual aparente, corta o equador celeste. Nessa data do ano ocorre a igualdade de duração entre o dia e a noite sobre toda a Terra.
\end{abstract}

Para análise dos Equinócios (em latitudes diferentes de zero grau), a utilização de um gnomon pode não ser tão atraente quanto para a interpretação dos Solstícios, logo, não se despenderá tempo neste estudo. Rees caracteriza alguns aspectos relevantes do Equinócio, como por exemplo, que a Terra se coloca de lado em relação ao Sol, evidenciando também a simetria entre as durações dos dias e das noites, aspectos estes válidos para todos os pontos da Terra (REES, 2008, p. 63).

Também se evidencia o fato de que, durante os Equinócios, o Sol se posiciona diretamente sobre a linha do equador, em seu movimento diurno aparente, aspecto marcante para um observador à Latitude zero. Neste caso, ao meio dia verdadeiro o Sol estará a pino e qualquer sombra será praticamente inexistente, o que seria interessante ser observado através de um gnomon.

\title{
III.1 O Equinócio Equatorial
}

Na Fig. 13, está representado um observador sobre a linha do equador. Neste caso, percebe-se que o equador celeste divide o céu em duas partes iguais. Durante o Equinócio, a interseção entre a eclíptica (trajetória aparente do Sol no decorrer do ano) e o equador celeste, que é uma característica intrínseca da esfera celeste, faz com que um observador à Latitude zero se encontre em uma posição especial, pois para ele o Sol cruzará o céu, de forma aparente, praticamente pelo equador celeste e, consequentemente, a projeção na Terra será sobre a linha do equador. Além disto, há outra coincidência astronômica, pois nos Equinócios o Sol nasce aproximadamente no leste e põe-se no oeste.

Na cidade de Macapá - AP, localizada sobre a linha do equador, ocorre uma festividade, duas vezes ao ano, durante a semana que ocorre o Equinócio, em março e em setembro, reconhecida internacionalmente. Porém, muitos não compreendem as características específicas para a Latitude zero e que tornam o fenômeno dos Equinócios tão importante para o povo amapaense, e não seria exagero mencionar que por vezes nem mesmo os próprios moradores do Amapá sabem o que significa o fenômeno que festejam a cada semestre.

É uma experiência muito interessante presenciar o Equinócio a partir do monumento marco-zero do equador (Fig. 14), em Macapá, onde o observador, ao posicionar-se sobre a linha do equador alinhado de frente para o obelisco, pode contemplar a plena visualização do movimento aparente do Sol praticamente sobre o equador, ao vislumbrá-lo pelo orifício na 
parte superior do obelisco, corroborando a teoria apresentada. Além disso, algumas frases "célebres" sempre se fazem presentes neste momento, como os que afirmam que somente um observador sobre a linha do equador pode presenciar o Equinócio (que é um fenômeno glo-

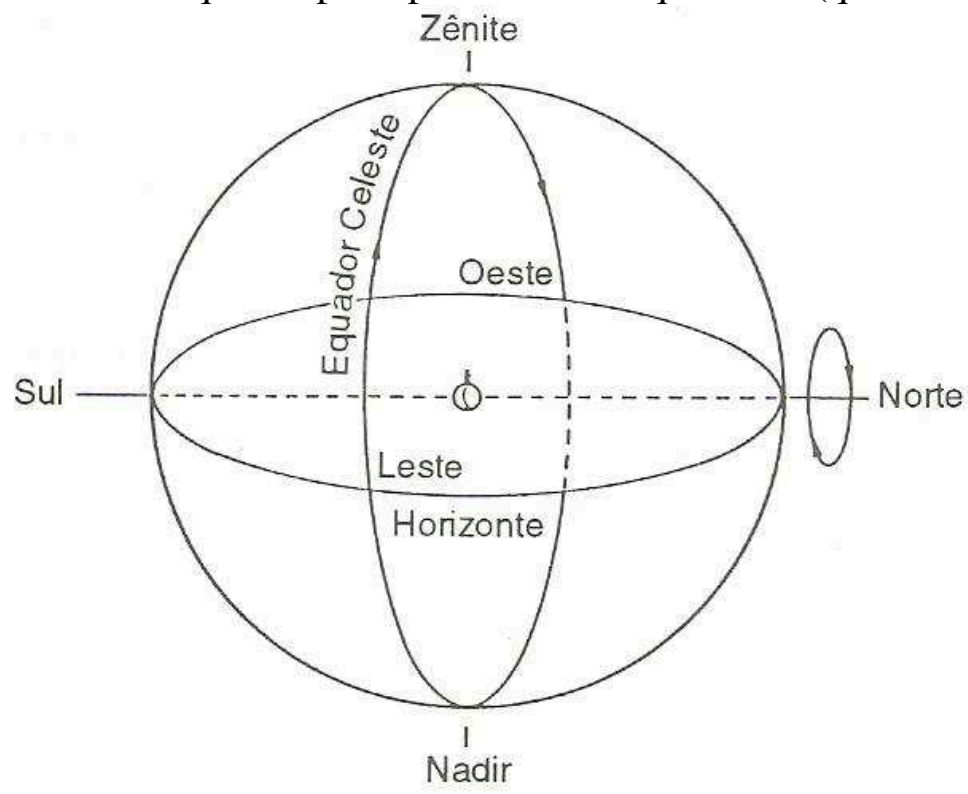

Fig. 13 - Observador sobre a linha do equador (MOURÃO, 2004, p. 14).

bal), além dos que aproveitam para suscitar superstições e crendices sobre este fenômeno "cheio de energia". Aos turistas que visitam tal monumento, em épocas distintas das que ocorrem os Equinócios, lhes resta a experiência de registrar em fotos que estiveram sobre a linha do equador, ao pisarem na linha demarcatória da mesma, presente em tal monumento.

Há ainda peculiaridades criadas na região pela população local, como a denominação dada ao equinócio de março, o qual é conhecido em todo o Estado do Amapá como Equinócio das águas, devido ao período de constantes chuvas que coincide com a época deste fenômeno (em março). Além disso, a festividade contempla os costumes locais, como danças e ritos culturais tradicionais, valorizando e divulgando a riqueza do povo amapaense.

Ao descrever a inclinação do eixo rotacional da Terra, assim como os movimentos aparentes entre a Terra e o Sol, permitiu-se explicar como ocorrem as estações do ano, assim como os momentos específicos de transição entre as mesmas, pontos estes denominados Solstícios e Equinócios, sendo que o primeiro marca o início do verão e do inverno, enquanto que o segundo marca o início da primavera e do outono. De posse dessas informações, analisou-se que o Equinócio observado a partir da Latitude zero possui como característica peculiar que o Sol cruza, de forma aparente, a esfera celeste dividindo-a em duas partes iguais, tendo o Sol sua projeção praticamente sobre a linha do equador, de modo que a sombra do obelisco do monumento marco-zero do equador estende-se por sobre a linha equatorial.

Finalmente, destaca-se a simetria entre o dia e a noite, os quais para um observador sobre a linha do equador possuem a mesma duração durante todo o ano; além da característica 
do nascer e do ocaso solar ocorrer aproximadamente no ponto leste e oeste, respectivamente, durante os equinócios.

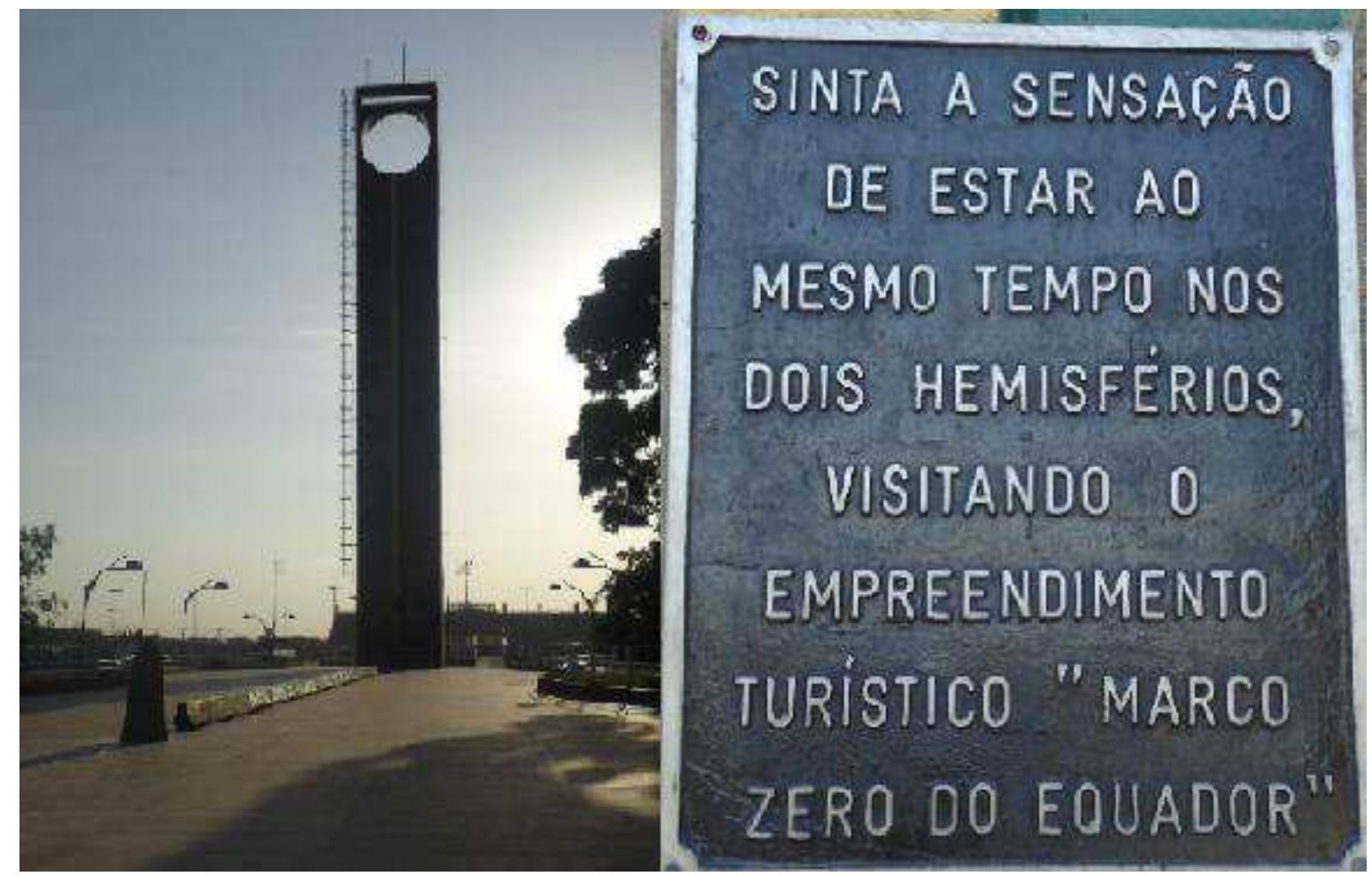

Fig. 14 - Monumento marco-zero do equador, em Macapá-AP e a inscrição contida em uma placa fixada no obelisco (SILVA, 2011).

\section{Conclusões}

A Astronomia é uma das Ciências mais antigas e importantes da humanidade, o que evidencia sua relevância para o progresso científico. Junto com esta certeza segue uma necessidade cada vez mais latente de disponibilidade de meios e métodos que ensejem facilitar a divulgação científica a respeito de temas relacionados com a Astronomia.

$\mathrm{O}$ enfoque dado neste trabalho, ao realizar uma análise física de alguns fenômenos astronômicos, tendo como referência observacional a Latitude zero (sobre a linha do equador), vem a preencher uma lacuna existente para a divulgação científica e que se mostra relevante devido às peculiaridades presentes no cotidiano local. Este tipo de enfoque é defendido por Oliveira, Voelzke e Amaral (2007, p. 97) ao apontarem a importância de "Discutir os conceitos de astronomia a partir dos fenômenos presentes no cotidiano do jovem e de suas concepções iniciais a respeito desses fenômenos", possibilitando valorizar conceitos populares e científicos.

A abordagem empregada, dispensando a utilização de complexos recursos matemáticos, almeja alcançar um público mais extenso que o acadêmico. Ao disponibilizar um texto 
com poucos termos técnicos e com a presença de diversas figuras ilustrativas e explicativas, busca-se oferecer um material acessível tanto aos interessados em geral quanto a educadores que possam consultá-lo e utilizá-lo para planejar e desenvolver suas aulas.

O uso de textos adequados ao ensino de conteúdos astronômicos constitui importante ferramenta que pode auxiliar os docentes em suas atividades didáticas, facilitando a abordagem destes conteúdos nos diferentes espaços da educação básica e servindo, inclusive, como elemento motivacional para a sua aprendizagem (OLIVEIRA, 2011; MARCHI; ALBUQUERQUE; LEITE, 2012).

O trabalho salientou a parcela visível da esfera celeste para a cidade de MacapáBrasil (sobre a linha do equador), utilizando Cartas Celestes de todos os meses do ano de 2016, mostrando que todas as 88 constelações foram passíveis de visualização nessa localidade, diferentemente do que acontece nas outras duas cidades analisadas.

Ao discutir o fenômeno do Equinócio, foi necessário explicar os fatores determinantes para a ocorrência das estações do ano, sendo fornecidas informações sobre os pontos de transição entre as estações, isto é, os Solstícios e os Equinócios. Além disso, foram esclarecidas as peculiaridades do fenômeno do Equinócio equatorial, analisando-o a partir do monumento marco-zero do equador na cidade de Macapá, no Brasil, onde se observa o Sol cruzando, de forma aparente, o equador celeste em um movimento por sobre a linha do equador.

Foi possível ilustrar que todo observador localizado sobre a linha do equador pode vislumbrar a plenitude da esfera celeste e constatar a ocorrência de coincidências de proporções astronômicas, como os Equinócios, e suas peculiaridades quando observados a partir da Latitude zero.

Enfim, os estudos dos movimentos da Terra e dos fenômenos a eles relacionados, como os Equinócios e a observação astronômica, precisam estar presentes em trabalhos de popularização científica, assim como em sala de aula no ensino básico. Para isto, o professor deve aproveitar os conhecimentos cotidianos dos alunos e utilizar os recursos disponíveis, pois desta forma permitirá que seja incentivado, desde a base, o interesse pela ciência e a percepção de sua interligação com o mundo. $\mathrm{O}$ entendimento dessa interligação fornece meios para que os estudantes possam compreender aspectos e fenômenos físicos relevantes relacionados ao seu contexto de vida e do mundo que o cerca permitindo, deste modo, criar condições favoráveis a um exercício mais adequado de sua cidadania (MORAES; ARAÚJO, 2012).

\section{Referências}

AFONSO, G. B. Experiências simples com o Gnomon. Revista Brasileira de Ensino de Física, v. 18, n. 3, p. 149-154, set. 1996.

ALBRECHT, E.; VOELZKE, M. R. Teaching of Astronomy and Scientific Literacy. Journal of Science Education, v. 11, n. 1, p. 36-38, jan. 2010. 
BERNARDES, A. O. Introduzindo textos com temas de Astronomia em sala de aula através da Coluna Astronomia e Educação. In: CONGRESSO NACIONAL DE EDUCAÇÃO, X, 2011, EDUCERE, Curitiba, Paraná.

BRETONES, P. S. (Org.). Jogos para o ensino de Astronomia. Campinas: Átomo, 2013. $115 \mathrm{p}$.

BRETONES, P. S.; MEGID NETO, J.; CANALlE, J. B. G. A Educação em Astronomia nos trabalhos das reuniões anuais da Sociedade Astronômica Brasileira. Boletim da Sociedade Astronômica Brasileira, v. 26, n. 2, p. 55-72, 2006.

CAPOZZOLI, U. Setembro traz de volta a primavera. Scientific American Brasil, Portugal, n. 112, p. 21, set. 2011.

ELIAS, D. C. N.; AMARAL, L. H.; ARAÚJO, M. S. T. Criação de um espaço de aprendizagem significativa no Planetário do Parque Ibirapuera. Revista Brasileira de Pesquisa em Educação em Ciências, v. 7, n. 1, p. 56-70, 2007.

FLAMMARION, C. Iniciação Astronômica. Lisboa: Aillaud e Bertrand, 1908. 210 p.

HART-DAVIS, A. Os primeiros Astrônomos. 160 Séculos de Ciência - A Aurora da Ciência, São Paulo, v. 1, p. 24-27, 2010.

IACHEL, G.; BACHA, M. G.; PAULA, M. P.; SCALVI, R. M. F. A montagem e a utilização de lunetas de baixo custo como experiência motivadora ao ensino de astronomia. Revista Brasileira de Ensino de Física, v. 31, n. 4, p. 4502-1-7, 2009.

IBGE. Noções básicas de Cartografia. Rio de Janeiro (1998). Disponível em: $<$ http://www.cartografica.ufpr.br/home/wp-content/uploads/2013/09/Nocoes-Basicas-

Cartografia.pdf>. Acesso em: 13 mai. 2017.

LANGHI, R. O caso de Cariclo: refletindo sobre o papel dos astrônomos na Educação em Astronomia. Revista Brasileira de Ensino de Física, v. 39, n. 4, e4303(1-6), 2017.

LANGHI, R.; NARDI, R. Educação em Astronomia: Repensando a Formação de Professores. São Paulo: Editora Escrituras, 2012. 215 p.

LANGHI, R.; NARDI, R. Ensino de Astronomia: Erros conceituais mais comuns presentes em livros didáticos de ciências. Caderno Brasileiro de Ensino de Física, v. 24, n. 1, p. 87 $111,2007$.

LANGHI, R.; VILAÇA, J. Educação em Astronomia no Brasil: Você sabe o que dizem os pesquisadores? Revista Planetária, v. 7, p. 6-9, 2015.

MAPA CELESTE INTERATIVO. Disponível em: <http://www.heavens-above.com/>. Acesso em: 11 dez. 2016. 
MARCHI, F.; ALBUQUERQUE, V. N.; LEITE, C. O caso Plutão: uma análise das potencialidades do uso de textos não didáticos no ensino de astronomia. Revista Electrónica de Enseñanza de las Ciencias, v. 11, n. 3, p. 565-581, 2012.

MORAES, J. U. P.; ARAÚJO, M. S. T. O ensino de Física e o enfoque CTSA: caminhos para uma educação cidadã. São Paulo: Livraria da Física, 2012. 144p.

MOURÃO, R. R. F. Manual do astrônomo. Rio de janeiro: Jorge Zahar Editor, 2004. 151 p. MOURÃO, R. R. F. Dicionário Enciclopédico de Astronomia e Astronáutica. Rio de janeiro: Nova Fronteira, 1987. 913 p.

OLIVEIRA, E. F.; VOELZKE, M. R.; AMARAL, L. H. Percepção astronômica de um grupo de alunos do ensino médio da rede estadual de São Paulo da cidade de Suzano. Revista Latino-Americana de Educação em Astronomia - RELEA, n. 4, p. 79-98, jul. 2007.

OLIVEIRA FILHO, K. S.; SARAIVA, M. F. O. Astronomia e Astrofísica. Porto Alegre: UFRGS, 2014. 784 p.

REES, M. As constelações. Enciclopédia Ilustrada do Universo. São Paulo: Duetto Editorial, 2008a. v. 4. 114p.

REES, M. Um mergulho no cosmos. Enciclopédia Ilustrada do Universo. São Paulo: Duetto Editorial, 2008b. v. 1. 114p.

SARAIVA, M. F. et al. Planisférios para o Brasil. Disponível em: $<$ http://www.if.ufrgs.br/ fatima/planisferio/celeste/planisferio.html>. Acesso em: 14 jan. 2017.

SILVA, J. N. Comunicação pessoal, 2011.

SILVA, P. J. M.; ARAÚJO, M. S. T.; VOELZKE, M. R. Introdução de tópicos de Astronomia para alunos do Ensino Médio: um caminho para o aprimoramento da aprendizagem conceitual. Revista Ciências \& Ideias, v. 5, n. 1, p. 19-38, 2014.

VOELZKE, M. R.; ARAÚJO, M. S. T. Plutão: Planeta ou "Planeta-Anão"? Revista de Ensino de Ciências e Matemática, v. 1, n. 1, p. 66-79, set. 2010. 